\title{
Analisa Biaya Penggunaan Bersama Jaringan Transmisi Kawasan BTDC Nusa Dua
}

\author{
Putu Agus Mahadi Putra ${ }^{1}$, Ida Ayu Dwi Giriantari ${ }^{2}$, Wayan Gede Ariastina ${ }^{3}$
}

\begin{abstract}
All around the world the deregulation of the electricity business sector is changing from a centralized and integrated into a segmented industry based on the competence of the business. A new form of trade with free access to transmission and distribution channels has encouraged a competitive trade between consumers and power plant owners. In such environments, the transmission network is considered a key factor in the electricity market. Utilization of the transmission of other companies to distribute electric power is commonly known as PBJT or Wheeling Transaction. The term PBJT in Indonesia is known as Joint Transmission Network Usage. There are several methods used to calculate the cost of lease transmission, in this paper used two cost allocation calculations that allow to be applied to the Bali electricity system ie, Postage-Stamp Rate method, MW-mile method. In this paper, we will apply the Postage Stamp Rate and $M W$-mile method of Wheeling Transaction in order to obtain the calculation of transmission lease cost acceptable by both parties.
\end{abstract}

Intisari- Di seluruh dunia deregulasi sektor bisnis listrik berubah dari suatu yang terpusat dan terintegrasi menjadi suatu industri tersegmentasi berdasarkan kompetensi para pelaku bisnis tersebut. Bentuk perdagangan baru dengan akses bebas pada saluran transmisi maupun distribusi telah mendorong suatu perdagangan kompetitif antar konsumen dan pemilik pembangkit. Pada lingkungan tersebut, jaringan transmisi dianggap sebagai faktor pokok dalam pasar listrik. Pemanfaatan transmisi perusahaan lain untuk menyalurkan tenaga listrik umumnya dikenal sebagai PBJT atau Wheeling Transaction. Istilah PBJT di Indonesia dikenal dengan Penggunaan Bersama Jaringan Transmisi. Ada beberapa metode yang digunakan untuk menghitung biaya sewa transmisi dalam paper ini digunakan dua perhitungan alokasi biaya yang memungkinkan untuk diaplikasikan pada sistem kelistrikan Bali yakni, metode PostageStamp Rate, metode MW-mile. Pada Paper ini, akan mengaplikasikan metode Postage Stamp Rate dan MW-mile dari Wheeling Transaction dengan tujuan untuk mendapatkan perhitungan biaya sewa transmisi yang dapat diterima oleh kedua belah pihak.

Kata Kunci - Transmisi, PBJT, Wheeling Transaction, PostageStamp Rate, MW-mile

\section{PENDAHULUAN}

Pulau Dewata Bali merupakan wilayah Indonesia yang sudah terkenal hingga mancanegara dalam sektor pariwisata. Ini terlihat dari tingkat pertumbuhan pembangunan yang tinggi, yakni hotel dan prasarana yang mendukung pariwisata. Pembangunan yang terus menerus terjadi tentu saja memicu permintaan akan kebutuhan listrik yang semakin meningkat.

\footnotetext{
${ }^{1}$ Mahasiswa Magister Teknik Elektro, Universitas Udayana, Kampus Pascasarjana Sudirman, Denpasar, Bali, INDONESIA;

2, 3 Dosen Magister Teknik Elektro, Universitas Udayana, Kampus Pascasarjana Sudirman, Denpasar, Bali, INDONESIA; e-mail: ${ }^{1}$ mahadi.putra@gmail.com, ${ }^{2}$ dayu.giriantari@yahoo.com, ${ }^{3}$ w_ariastina@yahoo.com
}

Maka dari itu Bali harus mampu menyeimbangkan antara pertumbuhan kebutuhan listrik dengan perkembangan pariwisatanya. Kawasan pariwisata yang luas dan penyumbang beban puncak cukup besar yakni, 57,5 MW[1] adalah di wilayah Nusa Dua tepatnya pada kawasan Bali Tourist Development Corporation (BTDC).

Di seluruh dunia deregulasi sektor bisnis listrik berubah dari suatu yang terpusat dan terintegrasi menjadi suatu industri tersegmentasi berdasarkan kompetensi para pelaku bisnis tersebut. Bentuk perdagangan baru dengan akses bebas pada saluran transmisi maupun distribusi telah mendorong suatu perdagangan kompetitif antar konsumen dan pemilik pembangkit. Pada lingkungan tersebut, jaringan transmisi dianggap sebagai faktor pokok dalam pasar listrik. Lokasi serta keterbatasan lahan menyebabkan infrastruktur ketenagalistrikan yang dimiliki suatu perusahaan tidak terdapat dalam satu lokasi. Sebagai contoh, suatu perusahaan yang berlokasi di kawasan padat akan menghadapi kesulitan untuk membangun PLTU yang membutuhkan lahan cukup luas. Pada kondisi ini, perusahaan tersebut dapat tetap membangun PLTU dengan konsekuensi berada di lokasi yang jauh. Disamping itu perusahaan tersebut juga harus membangun saluran transmisi.

Kondisi tersebut merupakan peluang bagi PT PLN (Persero). Pengelolaan ketenagalistrikan di Indonesia dilakukan oleh PT PLN (Persero) yang merupakan badan usaha milik negara. Kegiatan pengelolaan yang meliputi pembangkitan, penyaluran, pendistribusian dan penjualan energi kepada konsumen dilakukan oleh PLN dan anak perusahaanya[9]. PT PLN (Persero) dapat menyewakan jaringan yang dimilikinya kepada perusahaan tersebut. Bagi pemilik perusahaan, hal ini juga sangat menguntungkan karena membuat jaringan transmisi merupakan hal yang tidak mudah. Sewa jaringan ini tidak hanya untuk pemilik perusahaan, tetapi dapat pula untuk pemilik izin usaha penyediaan tenaga listrik. Pemanfaatan transmisi perusahaan lain untuk menyalurkan tenaga listrik ini umumnya dikenal sebagai PBJT. Istilah PBJT di Indonesia dikenal dengan Penggunaan Bersama Jaringan Transmisi. Payung hukum mekanisme PBJT ini telah terdapat pula pada UU Nomor 30 Tahun 2009 tentang Ketenagalistrikan [3]. Dengan demikian, harga transmisi harus menjadi indikator ekonomi yang wajar digunakan oleh PLN untuk membuat keputusan pada alokasi sumber daya, ekspansi sistem, dan penguatan. Maka dalam hal ini perhitungan yang digunakan untuk menghitung biaya sewa/penggunaan bersama jaringan transmisi ialah Wheeling Transaction.

Perhitungan Wheeling Transaction atau disebut juga Power Wheeling dimana tercantum di peraturan pemerintah no 14 tahun 2012 pasal 4,5,6 pada prinsipnya merupakan pemanfaatan bersama jaringan transmisi oleh pemegang izin usaha penyediaan tenaga listrik lainnya untuk menyalurkan 
daya dari pembangkit pihak tersebut di suatu tempat ke beban khusus pihak tersebut di tempat lain, dengan membayar sewa/biaya transmisi. Ada beberapa metode yang digunakan untuk menghitung biaya sewa transmisi yang telah banyak digunakan dan dipublikasikan hingga saat ini, akan tetapi dalam Paper ini digunakan dua perhitungan alokasi biaya yang memungkinkan untuk diaplikasikan pada sistem kelistrikan Bali. Adapun kedua perhitungan itu yakni, metode Postage Stamp Rate, metode MW-mile. Metode Postage Stamp Rate secara tradisional digunakan oleh perusahaan listrik untuk mengalokasikan biaya transmisi tetap (Fixed Cost) di antara para pengguna layanan transmisi perusahaan listrik. Metode ini merupakan metode biaya tertanam (embedded cost). Metode $M W$-mile adalah adalah metode biaya tertanam (embedded cost) yang juga dikenal sebagai metode line-byline karena menganggap dalam perhitungannya, ada perubahan aliran transmisi MW dan panjang saluran transmisi dalam mile/km. [2].

Berdasarkan uraian diatas, sampai saat ini memang kebutuhan energi listrik pada kawasan BTDC masih disuplai dari PLN dan saat ini juga PLN rencananya dalam RUPTL 2013-2022 [2] mulai untuk menerapkan sistem Wheeling Transaction di Indonesia khususnya Bali. Skenario yang digunakan pada paper ini ialah, asumsi bahwa PLTU Celukan Bawang pada tahun ini sudah beroperasi. Kemudian manajemen pada kawasan BTDC membuat perjanjian saham (sebagai pemilik) pada PLTU Celukan Bawang, yang dimana lokasinya sangat jauh berada di Singaraja, sehingga harus menyewa jaringan transmisi listrik PLN. Dengan demikian maka pada Paper ini, akan mengaplikasikan metode Postage Stamp Rate dan MW-mile dari Wheeling Transaction dengan tujuan untuk mendapatkan perhitungan biaya sewa transmisi yang dapat diterima oleh kedua belah pihak. Sehingga nantinya perhitungan ini bisa diharapkan untuk diaplikasikan sebagai salah satu alternatif dalam penentuan harga dari sewa jaringan transmisi oleh PLN.

\section{STUDI LITERATUR}

\section{A. Metode Postage Stamp Rate}

Metode Postage Stamp Rate secara tradisional digunakan oleh utilitas listrik untuk mengalokasikan biaya transmisi tetap di antara para pengguna layanan transmisi perusahaan. Metode ini merupakan metode biaya tertanam (embedded cost method), yang juga disebut the rolled-in embedded method. Metode ini tidak memerlukan perhitungan aliran daya dan independen dari jarak transmisi dan konfigurasi jaringan [2].

Metode ini sangat populer karena sangat sederhana, namun mengabaikan arus listrik sistem yang sebenarnya. Biaya transmisi untuk skema ini dapat ditulis secara matematis sebagai [4]:

$W C_{t}=T C \times \frac{P_{T}}{P_{P e a k}}$

dimana :

WCt : Biaya sewa jaringan transmisi untuk pengguna $(\mathrm{Rp} / \mathrm{kWh})$

TC : Biaya keseluruhan jaringan transmisi (Rp)

$\mathrm{Pt} \quad$ : Energi yang ditransmisikan dalam rentang waktu tertentu $(\mathrm{kWh})$
Ppeak : Energi yang diproduksi oleh sistem eksisting dalam rentang waktu tertentu $(\mathrm{kWh})$

\section{B. Metode $M W$-mile}

Metode $M W$-mile adalah metode biaya tertanam yang juga dikenal sebagai line-by-line metode karena menganggap dalam perhitungannya perubahan arus transmisi MW dan panjang saluran transmisi dalam mile [2]. Di indonesia, khususnya pada perusahaan PLN. Metode $M W$-Mile disebut dengan Metode Aliran Daya dan Jarak (MW-km) digunakan untuk menetapkan tarif jasa transmisi berdasarkan basis aliran daya yang melalui transmisi dan jarak transmisi. Model aliran daya digunakan untuk mengestimasi MW-km penggunaan oleh pembangkit dan beban untuk menciptakan tarif transmisi. Metode $M W$-Mile memiliki tiga varian dalam penerapannya [5]:

1. Pendekatan Absolute MW-Mile,

2. Pendekatan Reverse MW-Mile,

3. Pendekatan Dominant MW-Mile.

Secara umum besar pendapatan jasa transamisi berdasarkan Metode Aliran Daya dan Jarak (MW-km) dapat dinyatakan dengan formula sebagai berikut:

$\mathbf{T L C}=\mathbf{L} \times \mathbf{C} \times \frac{\Delta \mathbf{P}}{\mathbf{P}_{\text {Max }}}$

dimana :

TLC : Biaya Jasa Transmisi (Transmision Line Charge)

(Rp)

$\Delta \mathrm{P} \quad$ : Perubahan aliran daya pada transmisi menggunakan model aliran daya (MW)

$\mathrm{P}_{\text {Max }}$ : Daya maksimum pada masing - masing saluran (MW)

L : Panjang transmisi $(\mathrm{km})$

C : Biaya rata-rata transmisi (Rp/MW-km per bulan)

\section{Metode Aliran Daya}

Analisis aliran daya dapat digunakan untuk memperoleh informasi menganai sistem kerja aliran daya ketenagalistrikan dalam kondisi operasi tunak. Analisis aliran daya dapat menganalisis pembangkitan sistem kelistrikan dan pembebanan yang mengalir pada saat analisis. Hasil analisis dapat digunakan sebagai bahan evalusi sistem kelistrikan. Analisis ini juga memerlukan informasi aliran daya dalam kondisi normal maupun darurat [6].

Studi aliran daya merupakan penentuan atau perhitungan tegangan, arus, daya aktif maupun daya reaktif yang terdapat pada berbagai titik jaringan listrik pada keadaan pengoperasian normal, baik yang sedang berjalan maupun yang diharapkan akan terjadi di masa yang akan datang. Masalah aliran daya mencakup perhitungan aliran dan tegangan sistem pada terminal tertentu atau bus tertentu. Representasi fasa tunggal selalu dilakukan karena sistem dianggap seimbang [6]. Tujuan analisis aliran daya adalah [8]:

1. Untuk mengetahui tegangan pada tiap-tiap bus yang ada pada sistem. Variasi tegangan yang diperbolehkan adalah $\pm 5 \%$.

2. Untuk mengetahui apakah semua peralatan memenuhi batas-batas yang ditentukan untuk menyalurkan daya yang diinginkan. 
3. Untuk memperoleh kondisi awal untuk studi-studi seperti studi analisis hubung singkat stabilitas dan pembebanan ekonomis.

\section{METHODOLOGI}

Pada Paper ini data diambil dai PT. PLN (Persero) Area Pelaksana Pemeliharaan (APP) Bali yang berlokasi di Jl. Abian Base, kelurahan Kapal, Kecamatan Mengwi, Kabupaten Badung dan di PT. PLN (Persero) Area Pengatur Distribusi (APD) Bali di Jalan Diponegoro No. 17 Denpasar. Data-data yang digunakan dalam paper ini (Terlampir), adalah sebagai berikut :

1. Data penghantar dan impedansi saluran pada sistem kelistrikan $150 \mathrm{KV}$ di Bali.

2. Data Kapasitor pada sistem kelistrikan $150 \mathrm{KV}$ di Bali.

3. Data Beban Harian Bali.

4. Data Pembangkitan Bali.

Skenario yang digunakan pada paper ini ialah, menggunakan asumsi bahwa PLTU Celukan Bawang pada tahun ini sudah beroperasi. Kemudian manajemen pada kawasan BTDC membuat perjanjian saham (sebagai pemilik) pada PLTU Celukan Bawang, yang dimana lokasinya sangat jauh berada di Singaraja, sehingga harus menyewa jaringan transmisi listrik PLN. Daya Listrik yang ingin di transmisikan adalah sebesar 57,5 MW, jadi menggunakan pembangkit pada PLTU celukan Bawang dengan mengatur pembangkit dari keadaan normal operasi 130 MW ditambahkan 57,5 MW untuk mencukupi kebutuhan beban pada kawasan BTDC menjadi 187,5 MW.

\section{SIMULASI DAN PEMBAHASAN}

Sistem tenaga listrik $150 \mathrm{KV}$ di Bali mempunyai jaringan transmisi yang terbentang sepanjang 768,8 KM dengan 15 Gardu Induk dan memiliki 37 saluran transmisi. Bentuk saluran yang digunakan pada jaringan transmisi $150 \mathrm{KV}$ di Bali terdiri dari dua jenis yaitu berupa saluran ganda (double circuit) dan berupa saluran tunggal (single circuit) dapat dilihat pada Gambar 1. Penyaluran daya pada sistem kelistrikan Bali disuplai oleh tiga pembangkit listrik yakni Pembangkit Listrik Tenaga Gas dan Uap (PLTGU) Gilimanuk dengan daya mampu sebesar 130 MW, Pembangkit Listrik Tenaga Gas dan Uap (PLTGU) Pemaron dengan daya mampu sebesar 80 MW, serta Pembangkit Listrik Tenaga Diesel (PLTD) Pesanggaran dengan daya mampu sebesar 337,5 MW serta tambahan suplai dari kabel laut dengan daya mampu 340 MW melalui sistem interkoneksi Jawa-Bali, sehingga sistem kelistrikan Bali tahun 2014 memiliki total suplai daya sebesar 887,5 MW.

\section{A. Perhitungan Aliran Daya}

Pada paper ini, untuk menghitung dan mensimulasikan aliran daya sistem Bali menggunakan bantuan program komputer Load Flow Simulator. Langkah awal yang dilakukan adalah memodelkan keseluruhan sistem kelistrikan Bali. Memasukkan semua data yang didapatkan berupa data penghantar, data kapasitor, data beban harian, dan data pembangkitan Bali.

Putu Agus Mahadi Putra : Analisa Biaya Penggunaan Bersama....

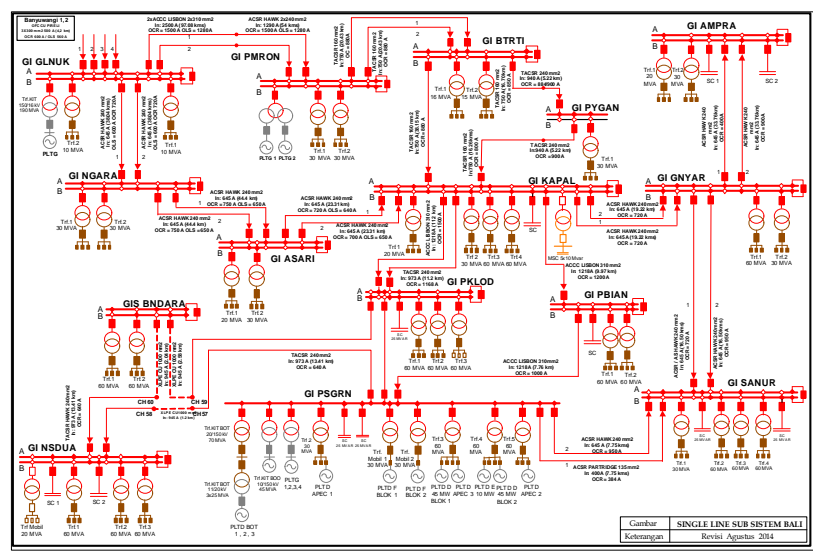

Gambar 1. Diagram segaris jaringan transmisi 150 KV di Bali Kondisi Exsisting

Kemudian melakukan simulasi pembangkitan di PLTU Celukan Bawang diatur dari 130 MW menjadi 187,5 MW. Gambar 2 merupakan Sistem Bali $150 \mathrm{KV}$ yang telah dimodelkan menggunakan bantuan program Load Flow Simulator.

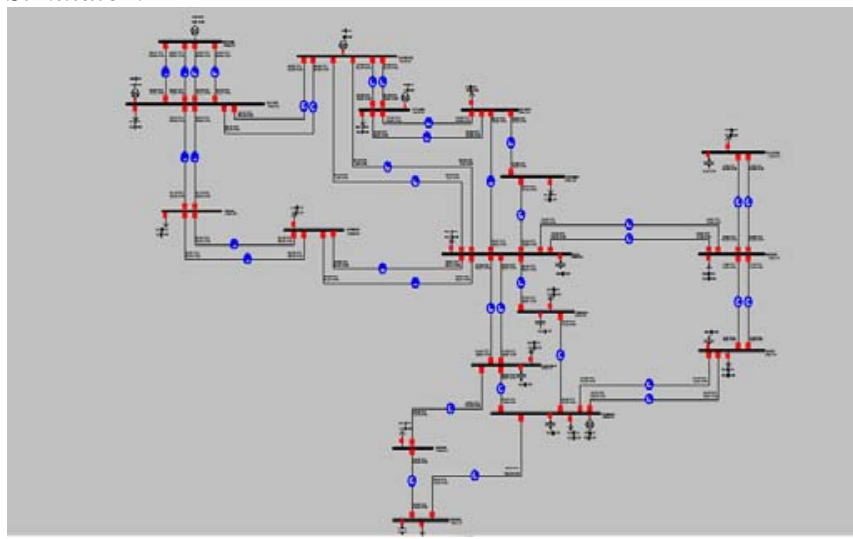

Gambar 2. Tampilan Sistem Bali pada Program Load Flow Simulator

Dengan menjalankan Program Load Flow Simulator, didapatkan hasil pada Tabel I dan Tabel II yakni :

Tabel I.

Tampilan Hasil pada Program Load Flow Simulator Pembangkitan PLTU Celukan Bawang $130 \mathrm{MW}$

\begin{tabular}{|l|l|l|}
\hline \multicolumn{3}{|c|}{ Area 1-1 } \\
\hline Number of Buses & 17 & \\
\hline Total Load & $585,2 \mathrm{MW}$ & $190,8 \mathrm{MVAR}$ \\
\hline Total Generation & $611,2 \mathrm{MW}$ & $-229,9 \mathrm{MVAR}$ \\
\hline Losses & $26,0 \mathrm{MW}$ & $-68,9 \mathrm{MVAR}$ \\
\hline Unserved Load & $0,0 \mathrm{MW}$ & \\
\hline Intercharge Error & 0,00 & \\
\hline
\end{tabular}

p-ISSN:1693 - 2951; e-ISSN: 2503-2372 
Tabel II.

Tampilan Hasil pada Program Load Flow Simulator Pembangkitan PLTU Celukan Bawang 187,5 MW

\begin{tabular}{|l|l|l|}
\hline \multicolumn{3}{|c|}{ Area 1-2 } \\
\hline Number of Buses & 17 & \\
\hline Total Load & $585,2 \mathrm{MW}$ & $190,8 \mathrm{MVAR}$ \\
\hline Total Generation & $609,3 \mathrm{MW}$ & $-235,0 \mathrm{MVAR}$ \\
\hline Losses & $24,0 \mathrm{MW}$ & $-73,8 \mathrm{MVAR}$ \\
\hline Unserved Load & $0,0 \mathrm{MW}$ & \\
\hline Intercharge Error & 0,00 & \\
\hline
\end{tabular}

Perhitungan menggunakan bantuan program Load Flow Simulator memperlihatkan perubahan pada nilai rugi-rugi daya yakni saat pembangkitan PLTU Celukan Bawang 130 MW, rugi-rugi yang dihasilkan sistem adalah sebesar 26 MW. Sedangkan saat pembangkitan di atur menjadi 187,5 MW rugi-rugi daya yang dihasilkan menjadi mengecil yakni sebesar 24,1. Selisih 1,9 MW ini membuktikan dengan beroperasinya PLTU Celukan Bawang pada sistem tenaga listrik Bali dapat meningkatkan kualitas dari sistem yang masih digunakan saat ini. Jadi ini dapat menjadi acuan bagi pihak PT PLN (Persero) untuk kedepannya dalam meningkatkan kualitas dari sistem tenaga listrik yang ada di Bali.

\section{B. Perhitungan Postage Stamp Rate}

Metode Postage Stamp Rate adalah metode paling sederhana yang sudah diterapkan di lingkungan PT PLN (Persero) dan juga di beberapa negara lain. Ini dikarenakan metode ini tidak mempengaruhi jaringan, letak jaringan, panjang jaringan, maupun tipe/jenis jaringan yang ada dan lebih dipengaruhi oleh biaya investasi dari suatu perusahaan. Penentuan biaya sewa jaringan dengan metode ini berdasarkan pada revenue requirement penyelenggaraan penyaluran dan besar produksi energi pada pembangkit. Total revenue requirement P3B 2013 dapat dilihat pada Tabel III.

Tabel III.

Revenue Requirement P3B 2013[7]

\begin{tabular}{|l|l|r|c|}
\hline No & \multicolumn{1}{|c|}{ Jenis } & \multicolumn{1}{c|}{ Nilai } & Keterangan \\
\hline 1 & Material Pemeliharaan & 456.352 & Juta Rupiah \\
\hline 2 & Jasa Borongan & 927.283 & Juta Rupiah \\
\hline 3 & Pegawai & 3.063 .757 & Juta Rupiah \\
\hline 4 & Administrasi & 776.897 & Juta Rupiah \\
\hline 5 & Penyusutan & 2.999 .910 & Juta Rupiah \\
\hline 6 & Bunga Pinjaman & 2.684 .974 & Juta Rupiah \\
\hline & Total & 10.909 .173 & Juta Rupiah \\
\hline
\end{tabular}

Dari Tabel III dapat dilihat bahwa total biaya penyaluran adalah Rp 10.909.173 juta untuk seluruh produksi energi yang disalurkan melalui jaringan tegangan tinggi dan tegangan ekstra tinggi sebesar 163.966 GWh[7]. Dengan menggunakan persamaan 2.1, maka biaya yang timbul untuk PBJT adalah $66,53 \mathrm{Rp} / \mathrm{kWh}$. Kemudian nilai 66,53 Rp/kWh dari metode Postage Stamp Rate ini digunakan sebagai nilai harga dasar transmisi pada perhitungan metode $M W$-mile. Kemudian proyeksi harga yang harus dibayarkan pihak BTDC kepada
PLN untuk mengirimkan daya sebesar 57,5 MW selama 1 hari, 1 bulan, maupun 1 tahun menggunakan metode Postage Stamp Rate dapat dilihat pada Tabel IV:

Tabel IV.

Proyeksi Harga PBJT Menggunakan Metode Postage Stamp Rate

\begin{tabular}{|c|c|c|c|}
\hline Metode & $\begin{array}{c}\text { Total } \\
\text { Wheeling } \\
\text { (Rp)/Hari }\end{array}$ & $\begin{array}{c}\text { Total } \\
\text { Wheeling } \\
(\mathrm{Rp}) / \text { Bulan }\end{array}$ & $\begin{array}{c}\text { Total Wheeling } \\
\text { (Rp)/Tahun }\end{array}$ \\
\hline $\begin{array}{c}\text { Postage } \\
\text { Stamp } \\
\text { Rate }\end{array}$ & 91.811 .400 & 2.754 .342 .000 & 33.052 .104 .000 \\
\hline
\end{tabular}

Sesuai dengan Tabel IV harga PBJT yang harus dibayarkan pihak BTDC kepada pihak PT PLN (Persero) menggunakan metode Postage Stamp Rate yakni, Rp 91.811.400/Hari, R R 2.754.342.000/Bulan, $\quad$ Rp 33.052.104.000/Tahun.

\section{Perhitungan $M W$-mile}

Metode $M W$-mile adalah metode biaya tertanam yang juga dikenal sebagai line-by-line metode karena menganggap dalam perhitungannya perubahan arus transmisi MW dan panjang saluran transmisi dalam mil atau km. Perhitungan menggunakan persamaan 2, dan hasil nilai Wheeling atau PBJT pada tiap-tiap saluran transmisi dapat dilihat pada tabel $\mathrm{V}$.

Tabel V.

Nilai Hasil PBJT Menggunakan Metode MW-mile

\begin{tabular}{|c|c|c|c|c|c|}
\hline No & Penghantar & Wheeling (Rp) & No & Penghantar & $\begin{array}{l}\text { Wheeling } \\
\text { (Rp) }\end{array}$ \\
\hline 1 & $\begin{array}{l}\text { Banyuwangi - } \\
\text { Gilimanuk } 1\end{array}$ & $-29.167,00617$ & 20 & $\begin{array}{l}\text { Kapal - } \\
\text { Baturiti }\end{array}$ & $59.218,18382$ \\
\hline 2 & $\begin{array}{l}\text { Banyuwangi - } \\
\text { Gilimanuk } 2\end{array}$ & $-29.167,00617$ & 21 & $\begin{array}{l}\text { Kapal - } \\
\text { Gianyar } 1\end{array}$ & $-85,02669738$ \\
\hline 3 & $\begin{array}{l}\text { Banyuwangi - } \\
\text { Gilimanuk } 3 \\
\end{array}$ & $-56.919,25237$ & 22 & $\begin{array}{l}\text { Kapal - } \\
\text { Gianyar } 2 \\
\end{array}$ & $-85,02669738$ \\
\hline 4 & $\begin{array}{l}\text { Banyuwangi - } \\
\text { Gilimanuk } 4\end{array}$ & $-56.922,48622$ & 23 & $\begin{array}{l}\text { Kapal - } \\
\text { Pemecutan } \\
\text { Kld 1 }\end{array}$ & 0 \\
\hline 5 & $\begin{array}{l}\text { Gilimanuk - } \\
\text { Negara } 1\end{array}$ & $-103.790,6562$ & 24 & $\begin{array}{l}\text { Kapal - } \\
\text { Pemecutan } \\
\text { Kld } 2\end{array}$ & $-65,68963063$ \\
\hline 6 & $\begin{array}{l}\text { Gilimanuk - } \\
\text { Negara } 2\end{array}$ & $-103.790,6562$ & 25 & $\begin{array}{l}\text { Kapal - Pd. } \\
\text { Sambian }\end{array}$ & 0 \\
\hline 7 & $\begin{array}{l}\text { Gilimanuk- } \\
\text { Celukan } \\
\text { Bawang } 1\end{array}$ & $-134.071,5935$ & 26 & $\begin{array}{l}\text { Baturiti - } \\
\text { Payangan }\end{array}$ & $18.968,66874$ \\
\hline 8 & $\begin{array}{l}\text { Gilimanuk- } \\
\text { Celukan } \\
\text { Bawang } 2\end{array}$ & $-134.071,5935$ & 27 & $\begin{array}{l}\text { Gianyar - } \\
\text { Amlapura } 1\end{array}$ & 0 \\
\hline 9 & $\begin{array}{l}\text { Celukan } \\
\text { Bawang- } \\
\text { Pemaron } 1\end{array}$ & $19.943,41223$ & 28 & $\begin{array}{l}\text { Gianyar - } \\
\text { Amlapura } 2\end{array}$ & 0 \\
\hline 10 & $\begin{array}{l}\text { Celukan } \\
\text { Bawang- } \\
\text { Pemaron } 2\end{array}$ & $19.943,41223$ & 29 & $\begin{array}{l}\text { Gianyar - } \\
\text { Sanur } 1\end{array}$ & $-71,93205512$ \\
\hline 11 & $\begin{array}{l}\text { Celukan } \\
\text { Bawang - } \\
\text { Kapal 1 }\end{array}$ & $57.701,95401$ & 30 & $\begin{array}{l}\text { Gianyar - } \\
\text { Sanur } 2\end{array}$ & $-72,462919$ \\
\hline 12 & $\begin{array}{l}\text { Celukan } \\
\text { Bawang - } \\
\text { Kapal } 2\end{array}$ & $57.701,95401$ & 31 & $\begin{array}{l}\text { Sanur - } \\
\text { Pesanggaran } \\
1\end{array}$ & $-386,4921266$ \\
\hline
\end{tabular}




\begin{tabular}{|c|l|r|r|l|c|}
\hline 13 & $\begin{array}{l}\text { Pemaron - } \\
\text { Baturiti 1 }\end{array}$ & $23.551,1096$ & 32 & $\begin{array}{l}\text { Sanur - } \\
\text { Pesanggaran } \\
2\end{array}$ & 274,279669 \\
\hline 14 & $\begin{array}{l}\text { Pemaron - } \\
\text { Baturiti 2 }\end{array}$ & $23.551,1096$ & 33 & $\begin{array}{l}\text { Pesanggaran } \\
- \text { Nusa Dua }\end{array}$ & 92,64017013 \\
\hline 15 & $\begin{array}{l}\text { Negara - } \\
\text { Antosari 1 }\end{array}$ & $-99.790,46414$ & 34 & $\begin{array}{l}\text { Pesanggaran } \\
- \text { Pd. } \\
\text { Sambian }\end{array}$ & 17,34863145 \\
\hline 16 & $\begin{array}{l}\text { Negara - } \\
\text { Antosari 2 }\end{array}$ & $-99.790,46414$ & 35 & $\begin{array}{l}\text { Pesanggaran } \\
\text { - Pemecutan } \\
\text { Kld }\end{array}$ & 44,71838027 \\
\hline 17 & $\begin{array}{l}\text { Antosari - } \\
\text { Kapal 1 }\end{array}$ & $-49.348,22109$ & 36 & $\begin{array}{l}\text { Pemecutan } \\
\text { Kld - } \\
\text { Bandara }\end{array}$ & $-86,93338347$ \\
\hline 18 & $\begin{array}{l}\text { Antosari - } \\
\text { Kapal 2 }\end{array}$ & $-49.348,22109$ & 37 & $\begin{array}{l}\text { Bandara - } \\
\text { Nusa Dua }\end{array}$ & $-58,10776995$ \\
\hline 19 & $\begin{array}{l}\text { Kapal - } \\
\text { Payangan }\end{array}$ & $17.710,94604$ & \multicolumn{3}{|c}{} \\
\cline { 1 - 6 }
\end{tabular}

Dari tabel V dapat dilihat bahwa hasilnya bervariasi dari setiap saluran-saluran yang ada, kemudian untuk melihat total nilainya berdasarkan pendekatan-pendekatan alokasi biaya pada metode $M W$-mile dapat dilihat pada tabel VI berikut

Tabel VI.

Pendekatan-pendekatan alokasi biaya pada metode $M W$-mile

\begin{tabular}{|c|c|c|}
\hline No & Pendekatan & Total Wheeling (Rp) \\
\hline 1 & Reverse & $-947.089,2919$ \\
\hline 2 & Dominant & $298.719,7371$ \\
\hline 3 & Absolute & $1.245 .809,029$ \\
\hline
\end{tabular}

Pada Tabel VI harga yang harus dibayarkan pihak BTDC untuk menyalurkan daya listrik sebesar 57,5 MW dalam PBJT sistem Bali yakni, Rp - 947.090 untuk pendekatan reverse, Rp 298.720 untuk pendekatan dominant, Rp 1.245.810 untuk pendekatan Absolute.

Pendekatan alokasi biaya yang digunakan pada Paper ini adalah pendekatan dominant, ini dikarenakan biaya pada pendekatan dominant ini merupakan pendekatan yang lebih adil untuk kedua belah pihak, penyewa (dalam hal ini pihak BTDC) maupun yang menyewakan (dalam hal ini pihak PLN) Jika menggunakan pendekatan reverse akan merugikan pihak yang menyewakan karena akan lebih menguntungkan pihak penyewa dan jika menggunakan pendekatan absolute akan merugikan pihak penyewa karena akan lebih menguntungkan pihak yang menyewakan. Selain itu juga nilai $(+)$ pada harga tersebut merupakan perubahan penambahan aliran daya pada saluran saat pembangkitan pada PLTU Celukan Bawang diatur dari 130 MW menjadi 187,5 MW. Kemudian untuk proyeksi harga yang harus dibayarkan pihak BTDC kepada PLN selama 1 hari , 1 bulan, maupun 1 tahun dapat dilihat pada Tabel VII.

Tabel VII.

Proyeksi Harga PBJT

\begin{tabular}{|c|l|r|r|r|}
\hline $\begin{array}{c}\mathrm{N} \\
\mathrm{o}\end{array}$ & $\begin{array}{c}\text { Pendekata } \\
\mathrm{n}\end{array}$ & $\begin{array}{c}\text { Total } \\
\text { Wheeling } \\
(\mathrm{Rp}) / \text { Hari }\end{array}$ & $\begin{array}{c}\text { Total } \\
\text { Wheeling } \\
(\mathrm{Rp}) / \text { Bulan }\end{array}$ & $\begin{array}{c}\text { Total } \\
\text { Wheeling } \\
(\mathrm{Rp}) / \text { Tahun }\end{array}$ \\
\hline 1 & Reverse & -22.730 .160 & -681.904 .800 & -8.182 .857 .600 \\
\hline 2 & Dominant & 7.169 .280 & 215.078 .400 & 2.580 .940 .800 \\
\hline 3 & Absolute & 29.899 .440 & 896.983 .200 & 10.763 .798 .400 \\
\hline
\end{tabular}

Putu Agus Mahadi Putra : Analisa Biaya Penggunaan Bersama....
Sesuai dengan Tabel VII harga PBJT yang harus dibayarkan pihak BTDC kepada pihak PT PLN (Persero) menggunakan metode $M W$-mile yakni, Rp 7.169.280/Hari, Rp 215.078.400/Bulan, Rp 2.580.940.800/Tahun.

D. Perbandingan Hasil Metode Postage Stamp Rate dan MWmile

Sesuai dengan hasil perhitungan dari metode Postage Stamp Rate dan MW-mile pada sistem kelistrikan Bali didapatkan perbandingan proyeksi harga yang harus dibayarkan selama 1 Hari, 1 Bulan, maupun 1 Tahun. Hasil perhitungannya dapat dilihat pada Tabel VIII.

Tabel VIII.

Perbandingan Proyeksi Harga PBJT Menggunakan Metode Postage Stamp Rate dan MW-mile

\begin{tabular}{|c|c|c|c|c|}
\hline $\begin{array}{c}\mathrm{N} \\
\mathrm{o}\end{array}$ & Metode & $\begin{array}{c}\text { Total Wheeling } \\
\text { (Rp)/Hari }\end{array}$ & $\begin{array}{c}\text { Total Wheeling } \\
(\mathrm{Rp}) / \text { Bulan }\end{array}$ & $\begin{array}{c}\text { Total Wheeling } \\
(\mathrm{Rp}) / \text { Tahun }\end{array}$ \\
\hline 1 & $\begin{array}{c}\text { Postage } \\
\text { Stamp Rate }\end{array}$ & 91.811 .400 & 2.754 .342 .000 & 33.052 .104 .000 \\
\hline 2 & MW-mile & 7.169 .280 & 215.078 .400 & 2.580 .940 .800 \\
\hline
\end{tabular}

\section{SIMPULAN}

Pada Tabel 7 dapat dlihat hasil perhitungan menggunakan metode Postage Stamp Rate harganya 13 kali lipat lebih mahal dibandingkan metode $M W$-mile dan jika dilihat dari prosentasenya sebesar $1280 \%$. \%. Ini diakibatkan karena pada perhitungan metode Postage Stamp Rate merupakan metode yang paling sederhana, dimana tidak mengikutsertakan utilisasi sistem dalam perhitungan dan juga mengabaikan aliran daya sistem yang sebenarnya, serta metode ini lebih dipengaruhi oleh biaya investasi dibandingkan keadaan jaringan transmisi yang sebenarnya.

Jadi pada Paper ini metode yang direkomendaskan kepada pihak PT.PLN (Persero) ialah metode MW-mile. Ini dikarenakan metode ini menggambarkan penggunaan jaringan transmisi yang sebenarnya karena menggunakan analisis aliran daya dalam perhitungannya. Jadi harga PBJT yang harus dibayarkan pihak BTDC kepada pihak PT PLN (Persero) menggunakan metode $M W$-mile yakni, Rp 7.169.280/Hari, Rp 215.078.400/Bulan, Rp 2.580.940.800/Tahun.

Analisa dari penggunaan metode Postage Stamp Rate, dan MW-mile dalam perhitungan PBJT atau wheeling transaction memberikan kontribusi dalam menentukan harga saluran transmisi dari sistem kelistrikan Bali. Walaupun dalam hasil perhitungannya metode Postage Stamp Rate harganya 13 kali lipat lebih mahal dibandingkan metode $M W$-mile. Kedepannya semoga perhitungan metode $M W$-mile dapat direkomendasikan kepada pihak PT PLN (Persero) sebagai acuan dalam penentuan harga saluran transmisi di Bali.

\section{REFERENSI}

[1] PLN APD Bali. Data Beban Harian. Bali. 2014

[2] Shahidehpour, M. Market Operations In Electric Power Systems Forecasting, Scheduling, and Risk Management. IEEE WileyInterscience, (ISBN 0471443379). 2002

[3] PLN. Rencana Usaha Penyediaan Tenaga Listrik PT PLN (Persero) 2013-2022. Jakarta. 2013

p-ISSN:1693 - 2951; e-ISSN: 2503-2372 
[4] Hassan. Wheeling Charges Methodology For Deregulated Electricity Markets Using Tracing-Based Postage Stamp Methods. International Journal of Integrated Engineering, Vol. 3 No. 2 (2011) p. 39-46. 2011

[5] Kharbas, M.. Transmission Tariff Allocation Using Combined MWMile \& Postage Stamp Methods. in IEEE PES Innovative Smart Grid Technologies. India. page 6-11, 2011. 2011

[6] Cekdin, C. Sistem Tenaga Listrik. Yogyakarta: ANDI Yogyakarta.2006

[7] PLN. Laporan Akhir Kajian Implementasi Penggunaan Bersama Jaringan Transmisi. Lembaga Kerjasama Fakultas Teknik Universitas Gajah Mada. 2014

[8] Mataram, Made. Profil Sistem Kelistrikan Bali Pasca GI Pemecutan Kelod Dan PLTU 780 MW Celukan Bawang Beroperasi. Majalah Teknologi Elektro: Vol. 9 No.1 Januari - Juni 2010

[9] S.Kumara, Nyoman. Telaah Terhadap Program Percepatan Pembangunan Listrik Melalui Pembangunan PLTU Batubara 10.000 MW. Majalah Teknik Elektro: Vol. 8No.1Januari-Juni2009 


\section{LAMPIRAN}

1. Data penghantar dan impedansi saluran pada sistem kelistrikan $150 \mathrm{KV}$ di Bali.

Tabel IX.

Spesifikasi Teknis Saluran Transmisi 150 KV Bali

\begin{tabular}{|c|c|c|c|c|c|}
\hline No & Penghantar & $\begin{array}{c}\text { Jenis } \\
\text { Penghantar }\end{array}$ & Penampang & $\begin{array}{c}\text { Panjang } \\
(\mathbf{k m})\end{array}$ & $\begin{array}{c}\text { KHA / } \\
\text { CCC } \\
\text { (A) }\end{array}$ \\
\hline \multirow{2}{*}{1} & \multirow{2}{*}{ Banyuwangi - Gilimanuk 1} & XLPE (CU) & $300 \mathrm{~mm}^{2}$ & 4,2 & 600 \\
\hline & & ACSR & $240 \mathrm{~mm}^{2}$ & 1,72 & 645 \\
\hline \multirow{2}{*}{2} & \multirow{2}{*}{ Banyuwangi - Gilimanuk 2} & XLPE (CU) & $300 \mathrm{~mm}^{2}$ & 4,2 & 600 \\
\hline & & ACSR & $240 \mathrm{~mm}^{2}$ & 1,72 & 645 \\
\hline \multirow{2}{*}{3} & \multirow{2}{*}{ Banyuwangi - Gilimanuk 3} & XLPE (CU) & $300 \mathrm{~mm}^{2}$ & 4,29 & 600 \\
\hline & & XLPE (CU) & $300 \mathrm{~mm}^{2}$ & 1,96 & 600 \\
\hline \multirow{2}{*}{4} & \multirow{2}{*}{ Banyuwangi - Gilimanuk 4} & XLPE (CU) & $300 \mathrm{~mm}^{2}$ & 4,31 & 600 \\
\hline & & XLPE (CU) & $300 \mathrm{~mm}^{2}$ & 1,96 & 600 \\
\hline 5 & Gilimanuk - Negara 1 & ACSR & $240 \mathrm{~mm}^{2}$ & 43,69 & 645 \\
\hline 6 & Gilimanuk - Negara 2 & ACSR & $240 \mathrm{~mm}^{2}$ & 43,69 & 645 \\
\hline 7 & Gilimanuk-Celukan Bawang 1 & ACCC & $2 \times 310 \mathrm{~mm}^{2}$ & 48,54 & 2500 \\
\hline 8 & Gilimanuk-Celukan Bawang 2 & ACCC & $2 \times 310 \mathrm{~mm}^{2}$ & 48,54 & 2500 \\
\hline 9 & Celukan Bawang-Pemaron 1 & ACSR & $2 \times 240 \mathrm{~mm}^{2}$ & 27,32 & 1200 \\
\hline 10 & Celukan Bawang-Pemaron 2 & ACSR & $2 \times 240 \mathrm{~mm}^{2}$ & 27,32 & 1200 \\
\hline 11 & Celukan Bawang - Kapal 1 & TACSR & $410 \mathrm{~mm} 2$ & 140 & 675 \\
\hline 12 & Celukan Bawang - Kapal 2 & TACSR & $410 \mathrm{~mm} 2$ & 140 & 675 \\
\hline 13 & Pemaron - Baturiti 1 & TACSR & $160 \mathrm{~mm}^{2}$ & 20,43 & 750 \\
\hline 14 & Pemaron - Baturiti 2 & TACSR & $160 \mathrm{~mm}^{2}$ & 20,43 & 750 \\
\hline 15 & Negara - Antosari 1 & ACSR & $240 \mathrm{~mm}^{2}$ & 44,23 & 645 \\
\hline 16 & Negara - Antosari 2 & ACSR & $240 \mathrm{~mm}^{2}$ & 44,23 & 645 \\
\hline 17 & Antosari - Kapal 1 & ACSR & $240 \mathrm{~mm}^{2}$ & 23 & 645 \\
\hline 18 & Antosari - Kapal 2 & ACSR & $240 \mathrm{~mm}^{2}$ & 23 & 645 \\
\hline \multirow{2}{*}{19} & \multirow{2}{*}{ Kapal - Payangan } & TACSR & $160 \mathrm{~mm}^{2}$ & 21,47 & 750 \\
\hline & & ACSR & $240 \mathrm{~mm}^{2}$ & 5,22 & 645 \\
\hline 20 & Kapal - Baturiti & TACSR & $160 \mathrm{~mm}^{2}$ & 38,15 & 750 \\
\hline 21 & Kapal - Gianyar 1 & ACSR & $240 \mathrm{~mm}^{2}$ & 19,22 & 645 \\
\hline 22 & Kapal - Gianyar 2 & ACSR & $240 \mathrm{~mm}^{2}$ & 19,22 & 645 \\
\hline 23 & Kapal - Pemecutan Kld 1 & ACCC & $310 \mathrm{~mm}^{2}$ & 11,2 & 1250 \\
\hline
\end{tabular}

Putu Agus Mahadi Putra : Analisa Biaya Penggunaan Bersama.... 


\begin{tabular}{|c|l|c|c|c|c|}
\hline 24 & Kapal - Pemecutan Kld 2 & TACSR & $240 \mathrm{~mm}^{2}$ & 11,2 & 973 \\
\hline 25 & Kapal - Pd. Sambian & ACCC & $310 \mathrm{~mm}^{2}$ & 9,97 & 1250 \\
\hline \multirow{2}{*}{26} & \multirow{2}{*}{ Baturiti - Payangan } & TACSR & $160 \mathrm{~mm}^{2}$ & 21,918 & 750 \\
\cline { 2 - 5 } & & ACSR & $240 \mathrm{~mm}^{2}$ & 5,22 & 645 \\
\hline 27 & Gianyar - Amlapura 1 & ACSR & $240 \mathrm{~mm}^{2}$ & 33,76 & 645 \\
\hline 28 & Gianyar - Amlapura 2 & ACSR & $240 \mathrm{~mm}^{2}$ & 33,76 & 645 \\
\hline 29 & Gianyar - Sanur 1 & ACSR & $240 \mathrm{~mm}^{2}$ & 16,26 & 645 \\
\hline 30 & Gianyar - Sanur 2 & ACSR & $240 \mathrm{~mm}^{2}$ & 16,38 & 645 \\
\hline 31 & Sanur - Pesanggaran 1 & ACSR & $135 \mathrm{~mm}^{2}$ & 7,74 & 400 \\
\hline 32 & Sanur - Pesanggaran 2 & ACSR & $240 \mathrm{~mm}^{2}$ & 7,75 & 645 \\
\hline \multirow{2}{*}{33} & \multirow{2}{*}{ Pesanggaran - Nusa Dua } & TACSR & $240 \mathrm{~mm}^{2}$ & 13,41 & 973 \\
\cline { 2 - 6 } & & XLPE (CU) & $1000 \mathrm{~mm}^{2}$ & 1,2 & 900 \\
\hline 34 & Pesanggaran - Pd. Sambian & ACCC & $310 \mathrm{~mm}^{2}$ & 7,6 & 1250 \\
\hline 35 & Pesanggaran - Pemecutan Kld & ACCC & $310 \mathrm{~mm}^{2}$ & 6,53 & 1250 \\
\hline \multirow{2}{*}{36} & \multirow{2}{*}{ Pemecutan Kld - Bandara } & TACSR & $240 \mathrm{~mm}^{2}$ & 11,13 & 973 \\
\cline { 3 - 6 } & & XLPE (CU) & $1000 \mathrm{~mm}^{2}$ & 2,58 & 900 \\
\cline { 2 - 6 } & TACSR & $240 \mathrm{~mm}^{2}$ & 7,12 & 973 \\
\hline
\end{tabular}

Sumber: PT. PLN (Persero) P3B APP Bali Pebruari 2015

Tabel X.

Impedansi Penghantar serta Line Charging Saluran Transmisi 150 KV Bali

\begin{tabular}{|c|c|c|c|c|}
\hline \multirow[b]{2}{*}{ No } & \multirow[b]{2}{*}{ Penghantar } & \multicolumn{3}{|c|}{ Impedansi Penghantar } \\
\hline & & Positive (Ohm) & Nol (Ohm) & $\begin{array}{c}\text { Line } \\
\text { Charging }\end{array}$ \\
\hline \multirow{2}{*}{1} & \multirow{2}{*}{ Banyuwangi - Gilimanuk 1} & $0.073+\mathrm{j} 0.127$ & $0,283+\mathrm{j} 0.381$ & $4,790 \times 10^{-4}$ \\
\hline & & $0.137+\mathrm{j} 0.397$ & $0.287+\mathrm{j} 1.191$ & $2 \times 10^{-5}$ \\
\hline \multirow{2}{*}{2} & \multirow{2}{*}{ Banyuwangi - Gilimanuk 2} & $0.073+\mathrm{j} 0.127$ & $0,283+\mathrm{j} 0.381$ & $4,790 \times 10^{-4}$ \\
\hline & & $0.137+\mathrm{j} 0.397$ & $0.287+\mathrm{j} 1.191$ & $2 \times 10^{-5}$ \\
\hline \multirow{2}{*}{3} & \multirow{2}{*}{ Banyuwangi - Gilimanuk 3} & $0.073+\mathrm{j} 0.127$ & $0,283+\mathrm{j} 0.381$ & $4,790 \times 10^{-4}$ \\
\hline & & $0.073+\mathrm{j} 0.127$ & $0,283+\mathrm{j} 0.381$ & $2,4 \times 10^{-4}$ \\
\hline \multirow{2}{*}{4} & \multirow{2}{*}{ Banyuwangi - Gilimanuk 4} & $0.073+\mathrm{j} 0.127$ & $0,283+\mathrm{j} 0.381$ & $4,790 \times 10^{-4}$ \\
\hline & & $0.073+\mathrm{j} 0.127$ & $0,283+\mathrm{j} 0.381$ & $2,4 \times 10^{-4}$ \\
\hline 5 & Gilimanuk - Negara 1 & $0.137+\mathrm{j} 0.397$ & $0.287+\mathrm{j} 1.191$ & $1.380 \times 10^{-4}$ \\
\hline 6 & Gilimanuk - Negara 2 & $0.137+\mathrm{j} 0.397$ & $0.287+\mathrm{j} 1.191$ & $1.380 \times 10^{-4}$ \\
\hline 7 & Gilimanuk-Celukan Bawang 1 & $0,1102+\mathrm{j} \mathrm{0,286}$ & $0.2602+\mathrm{j} 0.858$ & $4,793 \times 10^{-4}$ \\
\hline 8 & Gilimanuk-Celukan Bawang 2 & $0,1102+\mathrm{j} \mathrm{0,286}$ & $0.2602+\mathrm{j} 0.858$ & $4,793 \times 10^{-4}$ \\
\hline
\end{tabular}




\begin{tabular}{|c|c|c|c|c|}
\hline 9 & Celukan Bawang-Pemaron 1 & $0,137+\mathrm{j} 0,397$ & $0.287+\mathrm{j} 1.191$ & $4,793 \times 10^{-4}$ \\
\hline 10 & Celukan Bawang-Pemaron 2 & $0,137+\mathrm{j} 0,397$ & $0.287+\mathrm{j} 1.191$ & $4,793 \times 10^{-4}$ \\
\hline 11 & Celukan Bawang - Kapal 1 & $0,042+j 0,81$ & $0,072+\mathrm{j} \mathrm{0,244}$ & $2,03 \times 10^{-4}$ \\
\hline 12 & Celukan Bawang - Kapal 2 & $0,042+\mathrm{j} 0,81$ & $0,072+\mathrm{j} 0,244$ & $2,03 \times 10^{-4}$ \\
\hline 13 & Pemaron - Baturiti 1 & $0.214+\mathrm{j} 0.408$ & $0.364+\mathrm{j} 1.224$ & $2.974 \times 10^{-5}$ \\
\hline 14 & Pemaron - Baturiti 2 & $0.214+\mathrm{j} 0.408$ & $0.364+\mathrm{j} 1.224$ & $2.974 \times 10^{-5}$ \\
\hline 15 & Negara - Antosari 1 & $0.137+\mathrm{j} 0.397$ & $0.287+\mathrm{j} 1.191$ & $1.353 \times 10^{-4}$ \\
\hline 16 & Negara - Antosari 2 & $0.137+\mathrm{j} 0.397$ & $0.287+\mathrm{j} 1.191$ & $1.353 \times 10^{-4}$ \\
\hline 17 & Antosari - Kapal 1 & $0.137+\mathrm{j} 0.397$ & $0.287+\mathrm{j} 1.191$ & $7.035 \times 10^{-5}$ \\
\hline 18 & Antosari - Kapal 2 & $0.137+\mathrm{j} 0.397$ & $0.287+\mathrm{j} 1.191$ & $7.035 \times 10^{-5}$ \\
\hline \multirow{2}{*}{19} & \multirow{2}{*}{ Kapal - Payangan } & $0.214+\mathrm{j} 0.408$ & $0.364+\mathrm{j} 1.224$ & $7.156 \times 10^{-5}$ \\
\hline & & $0.137+\mathrm{j} 0.397$ & $0.287+\mathrm{j} 1.191$ & $7.156 \times 10^{-5}$ \\
\hline 20 & Kapal - Baturiti & $0.214+\mathrm{j} 0.408$ & $0.364+\mathrm{j} 1.224$ & $5.555 \times 10^{-5}$ \\
\hline 21 & Kapal - Gianyar 1 & $0.137+\mathrm{j} 0.397$ & $0.287+\mathrm{j} 1.191$ & $6.068 \times 10^{-5}$ \\
\hline 22 & Kapal - Gianyar 2 & $0.137+\mathrm{j} 0.397$ & $0.287+\mathrm{j} 1.191$ & $6.068 \times 10^{-5}$ \\
\hline 23 & Kapal - Pemecutan Kld 1 & $0.1102+\mathrm{j} 0.286$ & $0.2602+\mathrm{j} 0.858$ & $3.200 \times 10^{-5}$ \\
\hline 24 & Kapal - Pemecutan Kld 2 & $0.127+\mathrm{j} 0.338$ & $0.277+\mathrm{j} 1.164$ & $3.200 \times 10^{-5}$ \\
\hline 25 & Kapal - Pd. Sambian & $0.1102+\mathrm{j} 0.286$ & $0.2602+\mathrm{j} 0.858$ & $3.348 \times 10^{-5}$ \\
\hline \multirow{2}{*}{26} & \multirow{2}{*}{ Baturiti - Payangan } & $0.214+\mathrm{j} 0.408$ & $0.364+\mathrm{j} 1.224$ & $6.933 \times 10^{-5}$ \\
\hline & & $0.137+\mathrm{j} 0.397$ & $0.287+\mathrm{j} 1.191$ & $6.933 \times 10^{-5}$ \\
\hline 27 & Gianyar - Amlapura 1 & $0.137+\mathrm{j} 0.397$ & $0.287+\mathrm{j} 1.191$ & $1.066 \times 10^{-4}$ \\
\hline 28 & Gianyar - Amlapura 2 & $0.137+\mathrm{j} 0.397$ & $0.287+\mathrm{j} 1.191$ & $1.066 \times 10^{-4}$ \\
\hline 29 & Gianyar - Sanur 1 & $0.137+\mathrm{j} 0.397$ & $0.287+\mathrm{j} 1.191$ & $5.019 \times 10^{-5}$ \\
\hline 30 & Gianyar - Sanur 2 & $0.137+\mathrm{j} 0.397$ & $0.287+\mathrm{j} 1.191$ & $5.093 \times 10^{-5}$ \\
\hline 31 & Sanur - Pesanggaran 1 & $0.236+\mathrm{j} 0.429$ & $0.386+\mathrm{j} 1.288$ & $2.257 \times 10^{-5}$ \\
\hline 32 & Sanur - Pesanggaran 2 & $0.137+\mathrm{j} 0.397$ & $0.287+\mathrm{j} 1.191$ & $2.257 \times 10^{-5}$ \\
\hline \multirow{2}{*}{33} & \multirow{2}{*}{ Pesanggaran - Nusa Dua } & $0.127+\mathrm{j} 0.338$ & $0.277+\mathrm{j} 1.164$ & $1.46 \times 10^{-5}$ \\
\hline & & $0.026+\mathrm{j} 0.151$ & $0.176+\mathrm{j} 0.453$ & $3.42 \times 10^{-5}$ \\
\hline 34 & Pesanggaran - Pd. Sambian & $0.1102+\mathrm{j} 0.286$ & $0.2602+\mathrm{j} 0.858$ & $2.606 \times 10^{-5}$ \\
\hline 35 & Pesanggaran - Pemecutan Kld & $0.1102+\mathrm{j} 0.286$ & $0.2602+\mathrm{j} 0.858$ & $2.606 \times 10^{-5}$ \\
\hline \multirow{2}{*}{36} & \multirow{2}{*}{ Pemecutan Kld - Bandara } & $0.127+\mathrm{j} 0.338$ & $0.277+\mathrm{j} 1.164$ & $1.46 \times 10^{-5}$ \\
\hline & & $0.026+\mathrm{j} 0.151$ & $0.176+\mathrm{j} 0.453$ & $3.42 \times 10^{-5}$ \\
\hline \multirow{2}{*}{37} & \multirow{2}{*}{ Bandara - Nusa Dua } & $0.127+\mathrm{j} 0.338$ & $0.277+\mathrm{j} 1.164$ & $1.46 \times 10^{-5}$ \\
\hline & & $0.026+\mathrm{j} 0.151$ & $0.176+\mathrm{j} 0.453$ & $3.42 \times 10^{-5}$ \\
\hline
\end{tabular}

Sumber: PT. PLN (Persero) P3B APP Bali Pebruari 2015

2. Data Kapasitor pada sistem kelistrikan 150 KV di Bali.

Putu Agus Mahadi Putra : Analisa Biaya Penggunaan Bersama.... 
Tabel XI.

Kapasitor yang Terpasang Pada Sistem Kelistrikan 150 KV Bali

\begin{tabular}{|l|l|r|}
\hline No & \multicolumn{1}{|c|}{ Lokasi } & \multicolumn{1}{|c|}{$\begin{array}{c}\text { Daya Kapasitor } \\
\text { (MVAR) }\end{array}$} \\
\hline 1 & GI Kapal & 50 \\
\hline 2 & GI Nusa Dua & $2 \times 25$ \\
\hline 3 & GI Sanur & $25+50$ \\
\hline 4 & GI Pesanggaran & $2 \times 25$ \\
\hline 5 & GI Amlapura & 50 \\
\hline 6 & GI Pemecutan Kelod & 25 \\
\hline 7 & GI Padang Sambian & $\mathbf{3 5 0}$ \\
\hline \multicolumn{2}{|l|}{ Total Daya Kapasitor } & 2015 \\
\hline
\end{tabular}

Sumber: PT. PLN (Persero) P3B APP Bali Pebruari 2015

3. Data Beban Harian Bali.

Tabel XII.

Data Beban Harian Bali Tanggal 11 Nopember 2014

\begin{tabular}{|c|c|c|}
\hline No & Jam (Wita) & Beban (MW) \\
\hline 1 & $00.00-01.00$ & 528,9 \\
\hline 2 & $01.00-02.00$ & 516,2 \\
\hline 3 & $02.00-03.00$ & 502,1 \\
\hline 4 & $03.00-04.00$ & 484,6 \\
\hline 5 & $04.00-05.00$ & 504,7 \\
\hline 6 & $05.00-06.00$ & 504,2 \\
\hline 7 & $06.00-07.00$ & 503,6 \\
\hline 8 & $07.00-08.00$ & 655,2 \\
\hline 9 & $08.00-09.00$ & 626,3 \\
\hline 10 & $09.00-10.00$ & 660,3 \\
\hline 11 & $10.00-11.00$ & 671,8 \\
\hline 12 & $11.00-12.00$ & 670,8 \\
\hline 13 & $12.00-13.00$ & 671,7 \\
\hline 14 & $13.00-14.00$ & 693,7 \\
\hline 15 & $14.00-15.00$ & 702 \\
\hline 16 & $15.00-16.00$ & 683,2 \\
\hline 17 & $16.00-17.00$ & 673 \\
\hline 18 & $17.00-18.00$ & 674 \\
\hline 19 & $18.00-19.00$ & 780,9 \\
\hline 20 & $19.00-20.00$ & 768,4 \\
\hline 21 & $20.00-21.00$ & 735 \\
\hline 22 & $21.00-22.00$ & 669,6 \\
\hline 23 & $22.00-23.00$ & 619,5 \\
\hline 24 & $23.00-24.00$ & 581,4 \\
\hline & Beban Tertinggi & 780,9 \\
\hline & Beban Terendah & 484,6 \\
\hline & Rata- Rata & 628,3791667 \\
\hline
\end{tabular}


Sumber: PT. PLN (Persero) APD Bali Pebruari 2015

Tabel XII.

Data Beban pada masing-masing Gardu Induk Tanggal 11 Nopember 2014

\begin{tabular}{|c|c|c|c|c|c|c|c|c|c|}
\hline No & Gardu Induk & Trafo & $\begin{array}{l}\text { Daya } \\
\text { Aktif } \\
\text { (MW) }\end{array}$ & $\begin{array}{c}\text { Daya } \\
\text { Reaktif } \\
\text { (MVAR) }\end{array}$ & No & Gardu Induk & Trafo & $\begin{array}{c}\text { Daya } \\
\text { Aktif } \\
\text { (MW) }\end{array}$ & $\begin{array}{c}\text { Daya } \\
\text { Reaktif } \\
\text { (MVAR) }\end{array}$ \\
\hline \multirow[t]{3}{*}{1} & Gilimanuk & $\begin{array}{l}\text { Trafo } 1 \text { - } \\
\text { 10MVA }\end{array}$ & 3,816 & 0,8 & 10 & Sanur & $\begin{array}{l}\text { Trafo } 1 \text { - } \\
\text { 30MVA }\end{array}$ & 7,216 & 1,84 \\
\hline & & $\begin{array}{l}\text { Trafo } 2 \text { - } \\
\text { 10MVA }\end{array}$ & 5,84 & 1,328 & & & $\begin{array}{l}\text { Trafo } 2 \text { - } \\
\text { 60MVA }\end{array}$ & 11,448 & 3,504 \\
\hline & & Subtotal & 9,656 & 2,128 & & & $\begin{array}{l}\text { Trafo } 3 \text { - } \\
\text { 60MVA }\end{array}$ & 24,944 & 7,568 \\
\hline \multirow[t]{3}{*}{2} & Negara & $\begin{array}{l}\text { Trafo } 1 \text { - } \\
\text { 30MVA }\end{array}$ & 4,56 & 1,696 & & & $\begin{array}{l}\text { Trafo } 4 \text { - } \\
\text { 60MVA }\end{array}$ & 15,28 & 3,992 \\
\hline & & $\begin{array}{l}\text { Trafo } 2 \text { - } \\
\text { 30MVA }\end{array}$ & 8,08 & 1,496 & & & Subtotal & 58,888 & 16,904 \\
\hline & & Subotal & 12,64 & 3,192 & 11 & Padangsambian & $\begin{array}{l}\text { Trafo } 1 \text { - } \\
\text { 60MVA }\end{array}$ & 33,04 & 13,112 \\
\hline \multirow[t]{3}{*}{3} & Antosari & $\begin{array}{l}\text { Trafo } 1 \text { - } \\
\text { 20MVA }\end{array}$ & 9,36 & 1,872 & & & $\begin{array}{l}\text { Trafo } 2 \text { - } \\
\text { 60MVA }\end{array}$ & 19,888 & 6,048 \\
\hline & & $\begin{array}{l}\text { Trafo } 2 \text { - } \\
\text { 30MVA }\end{array}$ & 2,256 & $-0,2$ & & & Subtotal & 52,928 & 19,16 \\
\hline & & Subtotal & 11,616 & 1,672 & 12 & $\begin{array}{c}\text { Pemecutan } \\
\text { Kelod }\end{array}$ & $\begin{array}{l}\text { Trafo } 1 \text { - } \\
\text { 60MVA }\end{array}$ & 22,992 & 6,72 \\
\hline \multirow[t]{3}{*}{4} & Pemaron & $\begin{array}{l}\text { Trafo } 1 \text { - } \\
\text { 30MVA }\end{array}$ & 18,224 & 3,888 & & & $\begin{array}{l}\text { Trafo } 2 \text { - } \\
\text { 60MVA }\end{array}$ & 26,792 & 7,768 \\
\hline & & $\begin{array}{l}\text { Trafo } 2 \text { - } \\
\text { 30MVA }\end{array}$ & 17,2 & 2,456 & & & $\begin{array}{l}\text { Trafo } 3 \text { - } \\
\text { 60MVA }\end{array}$ & 12,848 & 4,416 \\
\hline & & Subtotal & 35,424 & 6,344 & & & Subtotal & 62,632 & 18,904 \\
\hline \multirow[t]{3}{*}{5} & Baturiti & $\begin{array}{l}\text { Trafo 1 - } \\
\text { 16MVA }\end{array}$ & 5,472 & 0,744 & 13 & Bandara & $\begin{array}{l}\text { Trafo } 1 \text { - } \\
\text { 60MVA }\end{array}$ & 14,24 & 3,784 \\
\hline & & $\begin{array}{l}\text { Trafo } 2 \text { - } \\
\text { 15MVA }\end{array}$ & 1,728 & 0,064 & & & $\begin{array}{l}\text { Trafo } 2 \text { - } \\
\text { 60MVA }\end{array}$ & 9,28 & 0,632 \\
\hline & & Subtotal & 7,2 & 0,808 & & & Subtotal & 23,52 & 4,416 \\
\hline \multirow[t]{3}{*}{6} & Payangan & $\begin{array}{l}\text { Trafo } 1 \text { - } \\
\text { 30MVA }\end{array}$ & 21,84 & 7,36 & 14 & Nusa Dua & $\begin{array}{l}\text { Trafo } 1 \text { - } \\
\text { 60MVA }\end{array}$ & 13,6 & 4,392 \\
\hline & & $\begin{array}{l}\text { Trafo } 2 \text { - } \\
\text { 30MVA }\end{array}$ & 2,24 & 0,08 & & & $\begin{array}{l}\text { Trafo } 2 \text { - } \\
\text { 60MVA }\end{array}$ & 23,096 & 5,576 \\
\hline & & Subtotal & 24,08 & 7,44 & & & $\begin{array}{l}\text { Trafo } 3 \text { - } \\
\text { 60MVA }\end{array}$ & 20,8 & 4,768 \\
\hline \multirow[t]{5}{*}{7} & Kapal & $\begin{array}{l}\text { Trafo } 1 \text { - } \\
\text { 60MVA }\end{array}$ & 14,16 & 3,936 & & & $\begin{array}{c}\text { Trafo M - } \\
\text { 20MVA }\end{array}$ & 0 & 0 \\
\hline & & $\begin{array}{l}\text { Trafo } 2 \text { - } \\
\text { 30MVA }\end{array}$ & 22,296 & 6,152 & & & Subtotal & 57,496 & 14,736 \\
\hline & & $\begin{array}{l}\text { Trafo } 3 \text { - } \\
\text { 60MVA }\end{array}$ & 24,808 & 6,544 & 15 & Pesanggaran & $\begin{array}{l}\text { Trafo } 1 \text { - } \\
\text { 30MVA }\end{array}$ & 0 & 0 \\
\hline & & $\begin{array}{l}\text { Trafo } 4 \text { - } \\
\text { 60MVA }\end{array}$ & 26,856 & 7,776 & & & $\begin{array}{l}\text { Trafo } 2 \text { - } \\
\text { 30MVA }\end{array}$ & 0 & 0 \\
\hline & & Subtotal & 88,12 & 24,408 & & & $\begin{array}{l}\text { Trafo } 3 \text { - } \\
\text { 60MVA }\end{array}$ & 22,48 & 9,888 \\
\hline \multirow[t]{3}{*}{8} & Gianyar & $\begin{array}{l}\text { Trafo } 1 \text { - } \\
\text { 60MVA }\end{array}$ & 32,344 & 11,536 & & & $\begin{array}{l}\text { Trafo } 4 \text { - } \\
\text { 60MVA }\end{array}$ & 20,672 & 25,52 \\
\hline & & $\begin{array}{l}\text { Trafo } 2 \text { - } \\
\text { 30MVA }\end{array}$ & 16,168 & 6,112 & & & $\begin{array}{l}\text { Trafo } 5 \text { - } \\
\text { 60MVA }\end{array}$ & 29,456 & 11,456 \\
\hline & & Subtotal & 48,512 & 17,648 & & & Subtotal & 72,608 & 46,864 \\
\hline \multirow[t]{3}{*}{9} & Amlapura & $\begin{array}{l}\text { Trafo } 1 \text { - } \\
\text { 20MVA }\end{array}$ & 10,496 & 3,408 & \multicolumn{3}{|c|}{ Total } & 585,176 & 190,76 \\
\hline & & $\begin{array}{l}\text { Trafo } 2 \text { - } \\
\text { 30MVA }\end{array}$ & 9,36 & 2,728 & & & & & \\
\hline & & Subtotal & 19,856 & 6,136 & & & & & \\
\hline
\end{tabular}

Sumber: PT. PLN (Persero) APD Bali Pebruari 2015

Putu Agus Mahadi Putra : Analisa Biaya Penggunaan Bersama.... 
4. Data Pembangkitan Bali.

Tabel XIII.

Pembangkitan Tenaga Listrik di Bali

\begin{tabular}{|c|c|c|c|c|}
\hline No. & Unit & $\begin{array}{l}\text { Daya } \\
\text { Terpasang } \\
(\mathrm{MW})\end{array}$ & $\begin{array}{l}\text { Daya } \\
\text { Mampu } \\
(\mathrm{MW})\end{array}$ & $\begin{array}{l}\text { Jenis Bahan } \\
\text { Bakar }\end{array}$ \\
\hline I. & PLTG Pesanggaran & & & \\
\hline 1 & Unit 1 & 21,35 & 16,00 & \\
\hline 2 & Unit 2 & 20,10 & 16,50 & HSD \\
\hline 3 & Unit 3 & 42,00 & 38,00 & \\
\hline 4 & Unit 4 & 42,00 & 37,00 & \\
\hline II. & PLTG Gilimanuk & & & \\
\hline 1 & Unit 1 & 133,80 & 130,00 & HSD \\
\hline III. & PLTG Pemaron & & & \\
\hline 1 & Unit 1 & 48,80 & 40,00 & HSD \\
\hline 2 & Unit 2 & 48,80 & 40,00 & \\
\hline IV. & PLTD A 30 MW Pesanggaran & & & \\
\hline 1 & Unit 1 & 11,52 & 9,00 & MFO \\
\hline 2 & Unit 2 & 11,52 & 8,00 & \\
\hline 3 & Unit 3 & 11,52 & 9,00 & \\
\hline $\mathrm{V}$. & PLTD B 50 MW Pesanggaran & & & \\
\hline 1 & Unit 1 & 18,00 & 16,80 & MFO \\
\hline 2 & Unit 2 & 18,00 & 16,80 & \\
\hline 3 & Unit 3 & 18,00 & 16,80 & \\
\hline VI. & PLTD C 50 MW Pesanggaran & & & \\
\hline 1 & Blok 1 & $14 \mathrm{X} 1.4 \mathrm{MW}$ & 18,00 & HSD \\
\hline 2 & Blok 2 & 13 X 1.4 MW & 18,00 & \\
\hline 3 & Blok 3 & $11 \mathrm{X} 1.4 \mathrm{MW}$ & 15,00 & \\
\hline VII. & PLTD D 45 MW Pesanggaran & & & \\
\hline 1 & Blok 1 & 18 X 1.4 MW & 25,00 & HSD \\
\hline 2 & Blok 2 & 15 X $1.4 \mathrm{MW}$ & 20,00 & \\
\hline VIII. & PLTD E 10 MW Pesanggaran & & & \\
\hline 1 & Blok 1 & $7 \times 1.6 \mathrm{MW}$ & 10,00 & MFO \\
\hline IX. & PLTD F 45 MW Pesanggaran & & & \\
\hline 1 & Blok 1 & $23 \times 0.95 \mathrm{MW}$ & 22,50 & HSD \\
\hline 2 & Blok 2 & $24 \times 0.95 \mathrm{MW}$ & 22,50 & \\
\hline \multicolumn{3}{|c|}{ Total Gilimanuk } & \multicolumn{2}{|l|}{$130 \mathrm{MW}$} \\
\hline \multicolumn{3}{|c|}{ Total Pemaron } & \multicolumn{2}{|l|}{$80 \mathrm{MW}$} \\
\hline \multicolumn{3}{|c|}{ Total Pesanggaran } & \multicolumn{2}{|l|}{$337.5 \mathrm{MW}$} \\
\hline \multicolumn{3}{|c|}{ Total Pembangkitan Sistem Bali } & \multicolumn{2}{|l|}{$547.5 \mathrm{MW}$} \\
\hline
\end{tabular}

Sumber: PT. PLN (Persero) P3B APP Bali Pebruari 2015 